\title{
Workplace Hygiene Practice among Saloon Workers in Bangladesh Army
}

\author{
Mohsin $\mathrm{M}^{1}$, Munir $\mathrm{AKMM}^{2}$
}

DOI: https://doi.org/10.3329/jafmc.v15i1.48650

\begin{abstract}
Introduction: In Bangladesh like any other developing country, saloon is the unique place for transmission of some communicable diseases.

Objectives: To explore the level of knowledge, attitude and practices regarding hygienic and cleanliness among saloon workers of Bangladesh Army.

Materials and Methods: This descriptive cross-sectional study was carried out in different barber shops of army units in Dhaka cantonment during the month of May 2011. Data were collected from 115 saloon worker by structured questionnaire through face to face interview.
\end{abstract}

Results: Mean age of 115 respondents' was $22.65 \pm 5.8$ years whereas $76 \%$ of the respondents have less than 5 years of service. Their monthly income was less than 8000 taka and $70.4 \%$ had only primary education. About $77 \%$ washed linen used for wrapping twice a week and $16.5 \%$ did it in alternate day. About $89.5 \%$ had awareness and knowledge of transmission of skin diseases through unclean comb, but only $2.6 \%$ did not have any knowledge regarding this matter. In case of disease spread through unclean handle of blade/khur majority $60 \%$ respondents were aware about skin disease but only $12 \%$ were aware about AIDS and $16.5 \%$ were aware about jaundice. Majority (90\%) found using antiseptic solution to clean used shaving brush /handle of razors. No respondent clean their hand before providing service to each customer and none used fresh linen for each customer rather 1 linen for every 10-12 customer on average.

Conclusion: The study revealed that majority of the saloon workers were either illiterate or had only primary plus level education with poor socio economic background. Despite the knowledge and practice of workplace hygiene among the saloon workers are quite satisfactory levels even though there are areas for further improvement.

Key-words: Workplace, Saloon, Barbar, Hygiene.

\section{Introduction}

Developing world is facing a burden of epidemics of blood borne diseases. These diseases increase the morbidity and mortality, ultimately resulting in heavy burden on national economics and individual level $\left.\right|^{12}$. An estimated, more than 180 million people worldwide are infected with hepatitis $\mathrm{C}$ virus $(\mathrm{HCV})$ and 3-4 million are newly infected each year ${ }^{3}$. It is a blood borne infection transmitted by infected blood and blood products through transfusions, contaminated needles, vertical transmission, unsafe use and reuse of razors by barbers 4 . The "Barber" profession has a very old history. The historical records of barbers indicate that they have an important role in the community ${ }^{5}$. Barbers at that times were considered as the medicine men and the scholars of their religion, they belonged to the groups who offer their services for bloodletting, circumcision, extraction of teeth and different types of minor operations. With the development of health sector, their role has been limited to haircutting and shaving only, 6 . 'The word hygiene is derived from 'Hygeia' the goddess of health in Greek Mythology. Hygiene is defined as the science of health and embraces all factors which contribute to healthful livings ${ }^{8}$. Good hygiene is always important for taking care of both mental and physical health. Workplace hygiene means a healthful condition in a working place and includes all factors which influence the health and well-being of the workers, which ultimately influence the service provided to customer. Workplace hygiene and cleanliness of a saloon consists of many activities such as adequate lighting, proper ventilation, clean floor, spacious sitting arrangement and habits regarding personal cleanliness using cleaned linen properly clean reusable brush, razors and combs.

Most of the people including military person visit saloon at least once in a month and they rushed there, spent some time before being served by the barber. Like many sources saloon is the unique place for transmission of some communicable diseases. Diseases that are most likely to be transmitted through a saloon are Bacterial infection; scabies, fungal infections, dandruff, and louse infestations, viral hepatitis even may be AIDS. But prevention of these diseases is possible if hygienic practice can be maintained by acquiring appropriate health knowledge through health education. The outcome of this current study will motivate the health educators, community developers and non-governmental organization to identify gaps and barriers in knowledge, attitude and practices of barbers with the impacts on disease transmission.

\section{Materials and Methods}

This descriptive cross sectional study was conducted in different barber shop of army units of Dhaka cantonment during the month of May 2011.All saloon workers working in the saloons of Dhaka cantonment were the study population. The sample size was one hundred and fifteen. All the respondents available in Dhaka cantonment during study period were within the sampling frame. A structured questionnaire was designed furnishing general information of the respondent. The questionnaire collected data about personal characteristics such as age, education, income, marital status, ethnic group and area of residence. The knowledge section covered barber's knowledge about different mode of transmission of Hepatitis, eczema and other skin diseases. The attitude section covers the source of media they used for information, attitude towards the disease, whether they are substance user or not. The practice of barber were observed regarding hand washing before each client was served, sterilization, use of antiseptic, use and reuse of blade and instruments. The purpose and importance of the study was explained to each respondent and data confidentiality was assured. The data was collected using a structured closed ended 
questionnaire in Bengali language to avoid language barrier. The data was analyzed using SPSS version 17.0.

\section{Results}

Out of 115 saloon worker $67 \%$ were belonging to Hindu religion. Mean age were $22.65 \pm 5.8$ years whereas $75.6 \%$ had less than 5 years of service, $70.5 \%$ had primary education and monthly incomes $73 \%$ had income less than 8000 taka per month. Maximum $77.4 \%$ respondents used to clean their working linen twice in a week. All (100\%) saloon workers did not wash their hands before serving every client. Among them $6.1 \%$ opined for customer satisfaction and perception of $93.9 \%$ respondents were prevention of infection. Approximately $60 \%$ of the saloon workers were aware about transmission of skin diseases through unclean Razor. About $61.7 \%$ respondents had knowledge regarding transmission of scabies and dermatitis through unclean comb.

Table-l: Distribution of respondents by socio-demographic characteristics $(n=115)$

\begin{tabular}{|l|l|c|c|}
\hline \multicolumn{2}{|c|}{ Characteristics } & Frequency & Percentage \\
\hline \multirow{4}{*}{ Age in years } & $\leq 20$ & 35 & 30.4 \\
\cline { 2 - 4 } & $21-30$ & 67 & 58.3 \\
\cline { 2 - 4 } & $>30$ & 13 & 11.3 \\
\cline { 2 - 4 } & Mean \pm SD $=22.65 \pm 5.8$ \\
\hline \multirow{4}{*}{ Education status } & Illiterate & 5 & 4.3 \\
\cline { 2 - 4 } & Primary & 81 & 70.5 \\
\cline { 2 - 4 } & Up to class VIII & 27 & 23.5 \\
\cline { 2 - 4 } & SSC & 2 & 1.7 \\
\hline \multirow{2}{*}{ Religion } & Islam & 38 & 33 \\
\cline { 2 - 4 } & Hindu & 77 & 67 \\
\hline \multirow{2}{*}{ Monthly income (Taka) } & $<8000$ & 84 & 73 \\
\cline { 2 - 4 } & $<8000$ & 31 & 27 \\
\hline \multirow{2}{*}{ Service experience (years) } & $<5$ & 28 & 24.3 \\
\cline { 2 - 4 } & $>5$ & & \\
\hline
\end{tabular}

Table-ll: Distribution of respondents by knowledge regarding cleanliness and transmission of diseases $(n=115)$

\begin{tabular}{|l|l|c|c|}
\hline \multicolumn{2}{|c|}{ Characteristics } & Frequency & Percentage \\
\hline \multirow{2}{*}{$\begin{array}{l}\text { Nature of solutions used } \\
\text { for cleaning of brushes/ } \\
\text { razors }\end{array}$} & Water & 1 & 0.9 \\
\cline { 2 - 4 } & Hot water and soap & 11 & 9.6 \\
\cline { 2 - 4 } $\begin{array}{l}\text { Purpose of antiseptic } \\
\text { lotion use }\end{array}$ & Antiseptic solution & 103 & 89.6 \\
\hline \multirow{4}{*}{$\begin{array}{l}\text { Frequency of working } \\
\text { linen washing }\end{array}$} & Prevention of infection & 108 & 93.9 \\
\cline { 2 - 4 } & Dustomer satisfaction & 7 & 6.1 \\
\cline { 2 - 4 } & Alternate day & 6 & 5.2 \\
\cline { 2 - 4 } & Twice weekly & 19 & 16.5 \\
\cline { 2 - 4 } & Weekly & 89 & 77.4 \\
\hline \multirow{3}{*}{$\begin{array}{l}\text { Knowledge about } \\
\text { transmission of diseases } \\
\text { through unclean comb }\end{array}$} & Scabies and dermatitis & 71 & 0.9 \\
\cline { 2 - 4 } & Eczema & 32 & 61.7 \\
\cline { 2 - 4 } & Lice & 09 & 27.8 \\
\cline { 2 - 4 } & Not known & 19 & 2.8 \\
\hline \multirow{2}{*}{$\begin{array}{l}\text { Knowledge about } \\
\text { transmission of diseases } \\
\text { through unclean razor }\end{array}$} & Jaundice & 69 & 16.5 \\
\cline { 2 - 4 } & Skin disease & 14 & 12.2 \\
\cline { 2 - 4 } & AlDS & 13 & 11.3 \\
\cline { 2 - 4 } & Not known & & \\
\hline
\end{tabular}

\section{Discussion}

This study was carried out to assess the knowledge, attitude of barbers regarding work place hygiene and their current practices. The study reveals that majorities of the saloon worker are belong to Hindu religion (67\%) and either illiterate or had only primary level of education $(70.4 \%)$. The percentage of the respondents gradually declined as higher grades of education were encountered. Mean age were $22.65 \pm 5.8$ years whereas $76 \%$ of the respondents have less than 5 years of service. Perhaps people do not like to remain in this profession too long. About the purpose of antiseptic lotion use, $6.1 \%$ opined for customer satisfaction and perception of $93.9 \%$ respondents were for prevention of infection. About the habit of hand washing all $(100 \%)$ did not wash their hands before serving every client. It was their usual practice of hand washing before and after completion of saloon works. Approximately $90 \%$ of the saloon workers were aware about transmission of skin diseases through unclean comb. In a related study conducted in ltaly noted that $90 \%$ of barbers washed hands after each customer handling, $66 \%$ did not change the towel after each customer ${ }^{9}$. Maximum numbers of respondents used to clean their working linen twice in a week hence all the linen were reusable. In case of disease transmission through unclean blade or khur majority $(60 \%)$ were aware about skin disease only few were aware (12\%) about AIDS and (16.5\%) regarding jaundice. In Islamabad and allied cities, a study was carried out by private university students which showed that barbers knowledge about Hepatitis $B$ \& C was very poor which is one of the key health issues of any developing country endorse the findings of current study. The study found out that $16.5 \%$ of barbers had knowledge about Hepatitis $\mathrm{B} \& \mathrm{C}$ affects liver and transmitted through infected razors ${ }^{10}$.

\section{Conclusion}

In the present study, it was observed that saloon workers of Dhaka cantonment had an acceptable level of awareness and knowledge about hygiene issues, their attitude toward such issues were nearly positive, despite some reluctance in practice were observed even though they had an acceptable level of hygiene performance as well. However, it seems to be still necessary to hold regular training courses to maintain the performance of these saloons at an acceptable level.

\section{References}

1. World Health Organization. Hepatitis B. Fact Sheet WHO/204.Geneva: WHO 2000.

2. World Health Organization Fact Sheet. 164: Hepatitis C. Geneva WHO 2000.

3. Shepard CW, Finelli L, Alter MJ. Global epidemiology of hepatitis C virus infection. Lancet Infec Dis 2005; 5:558-67.

4. Lopez AD, Mathers CD, Ezzati MD et al. Changes in individual behavior could limit the spread of infectious diseases. London: Oxford University Press, 2006.

5. Shalaby S, Kabbash IA, EI Saleet G et al. Hepatitis B and C viral infection: Prevalence, knowledge, attitude and practice among barbers and clients in Gharbia governorate, Egypt, East Mediterr Health J 2010; 16:10-7.

6. Waheed Y, Shafi T, Safi SZ, et al Hepatitis C virus in Pakistan: A systematic review of prevalence, genotypes and risk factors. World $\mathrm{J}$ Gastroenterol 2009; 15:5647-53.

7. Hamid S, Umar M, Alam A, et al PSG consensus statement on management of hepatitis C virus infection-2003. J Pak Med Assoc 2004; 54:146-50.

8. Park JE. Parks text book of preventive and social medicine,M/S Banarsidas Bhanot,Jabalpur,20th Ed 2009.

9. Mariano A, Mele A, Tosti ME et al. Role of beauty treatment in the spread of parenterally transmitted hepatitis viruses in Italy. J Med Virol 2004; 74(2):216-20.

10. Wazir MS, Mehmood S, Ahmed A et al. Awareness among barbers about Health hazards associated with their profession. J Ayub Med Coll Abbottabad 2008; 20:35-8. 